\title{
Target cells in haemoglobinopathies
}

\author{
L. R. DAVIS \\ From the Division of Pathology, King's College Hospital, London
}

SYNOPSIS A semi-quantitative method of estimating the number of target cells in blood films has been developed. It has been applied to 250 films from normal persons, pregnant women, and patients with a variety of haemoglobinopathies. Allowing for the frequency of target cells found in normal films the results show that such an examination is of value in eliminating or suggesting certain haemoglobinopathies, but not in excluding the majority of the traits.

It has become a standard procedure to screen immigrant members of the population for abnormal haemoglobins. The presence of target cells in a blood film may raise the suspicion of a haemoglobinopathy before the result of haemoglobin electrophoresis has become available. A simple, semi-quantitative method of assessing the number and significance of target cells has been developed and applied to blood films from normal persons and patients with the common haemoglobinopathies found in immigrants in South London.

\section{Method}

Blood films were made on coverslips and stained by the May-Grunwald-Giemsa technique on an automatic staining machine (Davidson, Bareham, Kitchen, and Pegg, 1958). The stained films were mounted on slides and examined with a $\times 40$ dry objective. Particular care was taken to examine those parts of the films in which the cells were spread in an even, single layer, and in which the normal red cells showed a clear central area. Only those cells with a clear zone round the central spot of haemoglobin were considered to be true target cells.

Cells with haemoglobin bridges joining the central spot to the peripheral ring, and polychromatic cells with a target-like appearance, were excluded, as these may be found quite frequently in normal films (Fig.).

On each film the target cells in 10 fields were counted and the average number per field determined. The results were allocated to one of four groups: no target cells seen; less than 1 target cell per field; 1 to $\mathbf{1 0}$ target cells per field; more than 10 target cells per field.

Received for publication 14 July 1971.

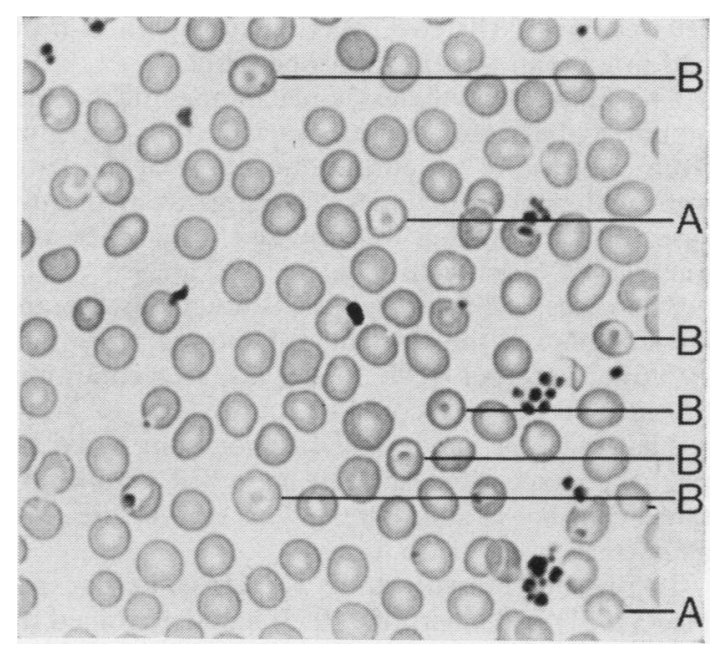

Fig. Photomicrograph of blood film showing the target cells (A) and cells resembling them (B).

\section{Material}

Normal films were from a group of students. Filıns of haemoglobin $\mathrm{S}$ and $\mathrm{C}$ traits were obtained from West Indian women in the first trimester of pregnancy.

To allow for any effects due to pregnancy or race, films from control groups of pregnant West Indian women without abnormal haemoglobins and pregnant European women were also examined. Films from other haemoglobinopathies were obtained from patients, including children and pregnant women, attending this group of hospitals. 


\section{Results}

Target cells were found in normal controls $(3 \cdot 3 \%)$, in pregnant European women $(2.5 \%)$, and rather more frequently in pregnant, but otherwise normal, West Indian women $(6.7 \%)$. In no case did the number of target cells reach 1 per field. Crosby (1952) concluded that for target cell formation the red cell needed a large surface area relative to its volume. The finding of occasional target cells in normal films might suggest that these were cells at the extreme range of normal variation in size and surface area and perhaps had only recently matured from reticulocytes.

Accepting less than 1 target cell per fieldasnormal, then $91 \%$ of the haemoglobin $S$ traits and $73 \%$ of the haemoglobin $\mathrm{C}$ traits were within normal limits. All the remaining haemoglobin $S$ traits and all but two of the haemoglobin $C$ traits had 1 to 10 target cells per field. The two other haemoglobin $C$ traits had more than 10 target cells per field.

The findings in thalassaemia minor and haemoglobin $\mathbf{S}$ thalassaemia were variable but the films from one case of the former and three of the latter were within normal limits. The films from the two cases of haemoglobin SD disease showed increased numbers of target cells.

The cases of haemoglobin SC and C disease and haemoglobin $C$ thalassaemia all showed more than 10 target cells per field. In the last two conditions few normal red cells could be found.

Thalassaemia major and haemoglobin $\mathbf{S}$ disease (with one exception) showed increased numbers of target cells but in addition the films showed the other characteristics of these diseases.

Before the present study Kaplan, Zuelzer, and Neel (1951) and Chernoff (1955) had determined the percentage of target cells in various haemoglobinopathies. With the exception of haemoglobin SD disease, in which condition Chernoff reported them to be infrequent, the three studies show good agreement.

From this study it was concluded that the finding of 1 or more target cells per high-power field was

\begin{tabular}{|c|c|c|c|c|c|}
\hline \multirow[t]{2}{*}{ Condition } & \multirow{2}{*}{$\begin{array}{l}\text { Number } \\
\text { of Films } \\
\text { Examined }\end{array}$} & \multicolumn{4}{|c|}{$\begin{array}{l}\text { Average Number of } \\
\text { Target Cells per Field }\end{array}$} \\
\hline & & 0 & 1 & $1-10$ & 10 \\
\hline $\begin{array}{l}\text { Normal } \\
\text { Antenatal women European } \\
\text { Antenatal women West Indian }{ }^{1} \\
\text { Haemoglobin S trait } \\
\text { Haemoglobin C trait } \\
\text { Thalassaemia minor } \\
\text { Haemoglobin S thalassaemia } \\
\text { Haemoglobin S disease } \\
\text { Thalassaemia major } \\
\text { Haemoglobin SD disease } \\
\text { Haemoglobin SC disease } \\
\text { Haemoglobin C disease } \\
\text { Haemoglobin C thalassaemia }\end{array}$ & $\begin{array}{r}31 \\
41 \\
48 \\
55 \\
37 \\
4 \\
5 \\
12 \\
3 \\
2 \\
8 \\
3 \\
1\end{array}$ & $\begin{array}{r}30 \\
40 \\
45 \\
37 \\
13 \\
1 \\
0 \\
0 \\
0 \\
0 \\
0 \\
0 \\
0\end{array}$ & $\begin{array}{r}1 \\
1 \\
3 \\
13 \\
14 \\
0 \\
3 \\
1 \\
0 \\
0 \\
0 \\
0 \\
0\end{array}$ & $\begin{array}{l}0 \\
0 \\
0 \\
5 \\
8 \\
2 \\
1 \\
3 \\
3 \\
1 \\
0 \\
0 \\
0\end{array}$ & $\begin{array}{l}0 \\
0 \\
0 \\
0 \\
2 \\
1 \\
1 \\
8 \\
0 \\
1 \\
8 \\
3 \\
1\end{array}$ \\
\hline Total & 250 & & & & \\
\hline
\end{tabular}

Table Number of target cells in various conditions

${ }^{1}$ Normal haemoglobin electrophoretic pattern.

abnormal and suggested a haemoglobinopathy. Examination of the blood film alone did not exclude the majority of the haemoglobinopathy traits. Increased numbers of target cells were the usual finding in the homozygous and double heterozygous states.

I wish to express my thanks to the technical staffs o d the laboratories, to Dr J. R. Rawstron for some the electrophoretic studies, and to Dr F. E. Dische for supplying some of the blood films. Dr K. G. A. Clarke and Mr S. H. Pegg kindly produced the photograph. Professor W. M. Davidson's advice and encouragement in preparing this report has been very much appreciated.

\section{References}

Chernoff, A. I. (1955). The human hemoglobin in health and disease. New Engl. J. Med., 253, 322-331, 365-374, 416-423.

Crosby, W. H. (1952). The pathogenesis of spherocytes and leptocytes (target cells). Analytical review. Blood, 7, 261-274.

Davidson, W. M., Bareham, F. R., Kitchen, L. D., and Pegg, S. H. (1958). An automatic staining machine designed for staining blood films made on coverslips. J. clin. Path., 11, 96-97.

Kaplan, E., Zuelzer, W. W., and Neel, J. V. (1951). A new inherited abnormality of hemoglobin and its interaction with sickle cell hemoglobin. Blood, 6, 1240-1259. 